Carlos Ayala Martínez, Patrick Henriet, Santiago Palacios Ontalva (eds.), Orígenes y Desarrollo de la Guerra Santa en la Península Ibérica. Palabras e Imágenes para una legitimación (siglos X-XIV)

\title{
António Rei
}

\section{OpenEdition}

\section{Journals}

Edição electrónica

URL: http://journals.openedition.org/medievalista/1380

DOI: $10.4000 /$ medievalista.1380

ISSN: 1646-740X

\section{Editora}

Instituto de Estudos Medievais - FCSH-UNL

\section{Refêrencia eletrónica}

António Rei, « Carlos Ayala Martínez, Patrick Henriet, Santiago Palacios Ontalva (eds.), Orígenes y Desarrollo de la Guerra Santa en la Península Ibérica. Palabras e Imágenes para una legitimación (siglos XXIV) », Medievalista [Online], 22 | 2017, posto online no dia 01 dezembro 2017, consultado o 23 setembro 2020. URL : http://journals.openedition.org/medievalista/1380 ; DOI : https://doi.org/ 10.4000/medievalista.1380

\section{(c) (1) 8}

Mediavalista está licenciado com uma Licença Creative Commons - Atribuição-NãoComercial 4.0 Internacional. 
Título / Title: Recensão: AYALA MARTÍNEZ, Carlos; HENRIET, Patrick; PALACIOS ONTALVA, Santiago (eds.) - Orígenes y Desarrollo de la Guerra Santa en la Península Ibérica. Palabras e Imágenes para una legitimación (siglos X-XIV). Madrid: Casa de Velázquez, 2016 (396 pp.)

Autor(es) / Author(s): António Rei Universidade / University: Universidade Nova de Lisboa

Faculdade e Departamento / Unidade de Investigação - Faculty and Department / Research Center: Universidade Nova de Lisboa, Faculdade de Ciências Sociais e Humanas, Intituto de Estudos Medievais / Consejo Superior de Investigaciones Científicas, Escuela de Estudios Árabes

Código Postal / Postcode: 1069-061

Cidade / City: Lisboa

País / Country: Portugal

Email Institucional / Institutional email: ajrei@sapo.pt

Fonte: Medievalista [Em linha]. Direc. Bernardo Vasconcelos e Sousa. Lisboa: IEM.

Disponível em:

http://www2.fcsh.unl.pt/iem/medievalista/MEDIEVALISTA22/rei2209.html ISSN: 1646-740X

Data de recepção do texto / Received for publication: 15 de Outubro de 2016 
Recensão: AYALA MARTÍNEZ, Carlos; HENRIET, Patrick; PALACIOS ONTALVA, Santiago (eds.) Orígenes y Desarrollo de la Guerra Santa en la Península Ibérica. Palabras e Imágenes para una legitimación (siglos X-XIV). Madrid: Casa de Velázquez, 2016 (396 pp.)

\author{
António Rei
}

Esta obra colige estudos em torno da origem e desenvolvimento da noção de Guerra Santa na Idade Média peninsular, a partir de testemunhos terminológicos e iconográficos, recolhidos em fontes de diferentes tipologias. Com uma extensão total de 396 páginas, todo o texto está em castelhano, com exceção das colaborações dos dois investigadores portugueses, em português. Tem uma Apresentação (pp. 1-3) e um Epílogo (pp. 327-336), estes da responsabilidade dos editores. No Epílogo, os dois primeiros autores da $\mathrm{V}$ parte surgem trocados, relativamente à ordem em que aparecem na coletânea.

A coletânea desenvolve-se em 5 partes:

\title{
I - Discurso Originario de la Guerra Santa Peninsular
}

Alexander Bronisch (pp. 7-29) questiona se se pode falar de guerra santa na Península Ibérica nos séculos X e XI. Naquele período ainda vigorava a cosmovisão hispano-goda, e em que a noção de pecado, por desobediência a Deus por parte da sociedade goda, trouxera a guerra, e seria pela guerra que teria que se dar a redenção.

Alejandro García Sanjuán (pp. 31-50) aborda a necessidade de uma ampliação da terminología relativa à guerra santa e ao jihâd. Propõe e analisa o termo fath (a raiz f-t-h

Medievalista online № 22 | Julho - Dezembro 2017 ๑ IEM - Instituto de Estudos Medievais 2 www2.fcsh.unl.pt/iem/medievalista 
significa: abertura, conquista, vitória). E, segundo o autor, em forma conclusiva, aquele termo deve ser considerado como o mais elevado na expressão literária e ideográfica da guerra santa, pois transmite a ideia daquilo que "por vontade de Deus" se abriu à conquista vitoriosa.

Hélène Sirantoine (pp. 51-65) identifica na documentação da monarquia castelhanoleonesa, e até à conquista de Toledo (1085), a recorrente ausência de formulações de sacralização relativamente à ação guerreira que vai sendo levada a cabo. É só depois da conquista da antiga capital do reino visigodo que a atividade bélica começa a ser associada à restauração da Igreja e à obtenção de graças espirituais.

\section{II - Lenguaje Cronístico y Literário de la Guerra Santa}

David Porrinas (pp. 69-86), através de uma análise do discurso cronístico, deteta terminologias que apontam à guerra santa e à cruzada. Esses termos e expressões, em especial a partir de meados do século XII, ajudam a constuir um discurso em que se transmite uma intensa presença de sacralização dos contextos da guerra, e do seu ator, o guerreiro.

Francisco García Fitz (pp. 87-102), afastando-se dos textos historiográficos clássicos, avança para diferentes fontes peninsulares, nomeadamente as literárias, e constata que uma ideia de cruzada, ligada ao protagonismo papal, e a outros elementos canónicos definidores da realidade da guerra santa, acaba por sobressair pela ausência discursiva e pelos silêncios textuais.

Philippe Josserand (pp. 103-113) refere que a cronística oficial castelhano-leonesa não omite referências à Cruzada do Oriente, embora haja uma desvalorização da mesma por comparação com a chamada “Cruzada do Ocidente” ou Reconquista, para que a nobreza peninsular não troque esta por aquela, e, dessa forma se desvincule dos objetivos traçados pelos monarcas reconquistadores.

Martín Rios Saloma (pp. 115-124) aborda a reconstrução do imaginário que a cronística mais tardia, dos séculos XIV e XV, fez sobre os enfrentamentos entre cristãos e 
muçulmanos que tiveram a Península Ibérica como palco. Essa reconstrução foi um meio que a monarquia usou, e cujo objetivo foi a criação de um conceito identitário de uma união, estruturada pela própria monarquia.

\section{III - Guerra Santa y Cancillería en torno a las Navas}

Martín Alvira Cabrer (pp. 127-153) analisa documentação das chancelarias régia e papal no reinado de Pedro II de Aragão, um dos intervenientes na Batalha de Navas de Tolosa (1212), a qual teve conotações de cruzada e de guerra santa. Esta análise acaba evidenciando uma situação problemática que envolve o monarca e a monarquia aragonesa, que então se encontravam entre duas cruzadas. Manifestando-se a favor da cruzada a sul, contra os muçulmanos, são, no entanto, contra a cruzada que tem lugar a norte, contra os cátaros e albigenses, e contra os senhores do Midi occitano, vassalos do rei aragonês.

Carlos de Ayala (pp. 155-185) constata que a entrada da Península para a cristandade romana foi intensificada com a receção da ideia primeira de Cruzada emanada do Papado em finais do século XI, e cujo processo culminou, em Castela, ao longo da segunda metade do século XII e primeiras décadas do século XIII, em especial no reinado de Afonso VIII (1158-1214).

Luís Filipe Oliveira (pp. 187-205), a partir das Inquirições ordenadas por Afonso II de Portugal em 1220, identifica, apesar da região em causa não ser já de fronteira contra o Islão, toda uma série de terminologias associadas às realidades bélicas, e especialmente nas áreas onde estavam mais presentes as ordens militares.

Damian J. Smith (pp. 207-218), identifica que na Chancelaria papal o conceito de cruzada e a recuperação da Graça Divina surge prioritariamente ligada à libertação de Jerusalém. Assim na documentação papal relativa à empresa cruzadística das Navas de Tolosa não surgem termos daquela natureza, nem a noção de martírio para os que nela morressem. O discurso cruzadístico é apenas veiculado por Afonso VIII de Castela e por aqueles que lhe eram próximos. 


\section{IV - Guerra Santa en la Perspectiva Bajomedieval}

Benjamin Weber (pp. 221-233) coloca uma questão: porque surge na Península Ibérica o termo “cruzada” um século depois da realidade que designa? Assinalando uma muito ténue relação com as empresas do Médio Oriente, o autor acaba por situar o contexto no momento em que, para além da luta reconquistadora na Península, está a acontecer a “cruzada” contra as heresias no Midi occitano. Conclui dizendo que tentar reduzir a polissemia do termo a uma definição unívoca e incontestável é algo destinado ao fracasso.

Manuel Rodríguez García (pp. 235-245) constata que o avançar do século XIII produz uma normalização do uso do termo cruzada, já sem subtilezas canónicas nem conteúdos doutrinais. Sem que, no entanto, seja posta de parte a vigência do "modelo hierosolimitano" enquanto referência ideal de toda a ação de cruzada.

Carlos Barquero (pp. 247-257) analisa a documentação peninsular produzida pela Ordem de S. João de Jerusalém, a qual incide mais sobre a cruzada do Oriente, embora também faça referências a ações bélicas de fronteira na Península entre os séculos XIII e XV. A documentação do século XIV, e no que ao Oriente diz respeito, começa a incidir sobre a necessidade de defesa dos domínios da Ordem ante a presença mameluca e o avanço dos otomanos.

\section{V - El Valor de la Representación Visual e Iconográfica}

Patrick Henriet (pp. 261-277) aborda o tema da eventual polémica anti-islâmica presente no Tractatus de Apocalipsis do Beato de Liébana. O estudo detalhado das passagens mais significativas não sugere qualquer alusão à guerra santa, nem alusões ao Islão como manifestação do Anti-Cristo. Donde a conclusão de que a exegese não será o modelo literário mais adequado para forjar e divulgar uma ideologia da guerra santa.

Fermín Miranda (pp. 279-296) propõe uma releitura, para o reino de Navarra, de imagens de obras famosas do século $X$, os códices Albeldense e Emilianense, e de alguns baixos-relevos, em especial os de San Miguel de Villatuerta. Encontra aí um elevado grau de sacralização da guerra, que irá aumentando até ao século XI. Alianças com chefes militares muçulmanos levam a um esbater ou mesmo desaparecer daquela 
retórica. E a mesma desaparece quase por completo quando a partir de 1134 Navarra deixou de ter fronteira direta a sul com o espaço andalusi.

Santiago Palacios Ontalva (pp. 297-310) analisa iconografias que evocam a guerra na Península, sem que, no entanto, as mesmas exprimam claramente uma ideologia da guerra santa. Se a este facto se junta a importação de modelos plásticos oriundos de contextos alheios aos meios onde as obras foram produzidas, convirá ter uma salutar prudência ao pretendermos estudar agora as obras em causa.

Isabel Cristina Fernandes (pp. 311-325) diz-nos não haver, em Portugal, muitos exemplos iconográficos da guerra contra os muçulmanos, surpreendendo mesmo pela escassez. E antes da Batalha do Salado não se constata uma representação, ou alusão, ao conflito entre cristãos e muçulmanos. E se não há muita documentação para o lado cristão, o mesmo parece suceder para o lado islâmico.

O volume termina com a extensa lista documental utilizada pelos autores, repartida em Fuentes (pp. 337-350) e Bibliografia (pp. 351-396).

\section{COMO CITAR ESTE ARTIGO}

\section{Referência electrónica:}

REI, António - "Recensão: AYALA MARTÍNEZ, Carlos; HENRIET, Patrick;

PALACIOS ONTALVA, Santiago (eds.) - Orígenes y Desarrollo de la Guerra Santa en la Península Ibérica. Palabras e Imágenes para una legitimación (siglos X-XIV).

Madrid: Casa de Velázquez, 2016 (396 pp.)”. Medievalista 22 (Julho-Dezembro 2017). [Em linha] [Consultado dd.mm.aaaa]. Disponível em http://www2.fcsh.unl.pt/iem/medievalista/MEDIEVALISTA22/rei2209.html ISSN 1646-740X. 


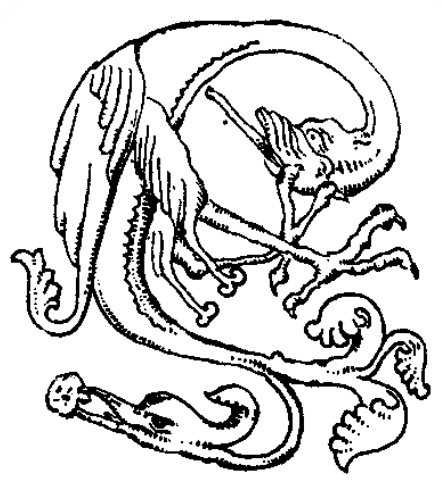

